\title{
ACCURACY ORDER OF THE GRAMMATICAL MORPHEMES IN THE ORAL PRODUCTION OF PRESCHOOL PUPILS
}

\author{
Jessie Barrot \\ Department of English and Applied Linguistics De La Salle University - Manila \\ email: jessie.barrot@dlsu.edu.ph \\ Kristine de Leon \\ Department of English and Applied Linguistics De La Salle University - Manila \\ email: kristine.deleon@dlsu.edu.ph
}

\begin{abstract}
There are numerous studies concerning the order of acquisition of grammatical morphemes; however, no paper to the knowledge of the authors has explored the accuracy order and acquisition of grammatical morphemes of Filipino children. The present study investigated the accuracy order of 14 English grammatical morphemes of Filipino preschool pupils. Specifically, this paper sought to determine the grammatical morphemes which have the highest and lowest accuracy level by Filipino preschool pupils. It also attempted to identify whether there is a relationship between the order of grammatical morpheme acquisition of Filipino preschool pupils compared to the order of grammatical morpheme wherein English is the first language and English is the second language. The participants involved in this study were 18 preschool pupils whose age ranges from three to five years old. These participants were divided into two clusters based on their linguistic and geographical background. The findings revealed that plurality and progressive verbs posted the highest accuracy level while prepositions and past irregular verbs had the lowest level of accuracy. As regards the relationship between the order of acquisition, the results revealed that the present study posted a different order compared to Dulay and Burt's (1973) and Brown's (1973) studies through Kendall coefficient of concordance and Spearman Rank Order Correlation.
\end{abstract}

Keywords: Accuracy order, L2 acquisition, order of acquisition, grammatical morphemes

\section{KEAKURATAN URUTAN MORFEM TATA BAHASA DALAM PRODUKSI LISAN SISWA PRA-SEKOLAH}

Abstrak: Ada banyak kajian mengenai urutan pemerolehan morfem-morfem tata bahasa, akan tetapi sepengetahuan penulis tidak ada makalah yang telah menggali keakuratan urutan dan pemerolehan morfem tata bahasa diantara anak-anak Filipina. Kajian ini menyelidiki keakuratan urutan dari empat belas morfem tata bahasa Inggris diantara siswa pra-sekolah Filipina. Khususnya, makalah ini berusaha untuk menentukan morfem-morfem tata bahasa yang memiliki tingkat keakuratan tertinggi dan terendah diantara siswa pra-sekolah Filipina. Kajian ini juga berusaha untuk melihat apakah ada hubungan antara urutan pemerolehan morfem tata bahasa para siswa pra-sekolah Filipina dengan urutan morfem tata bahasa dimana Inggris sebagai bahasa pertama dan kedua. Para peserta yang terlibat dalam kajian ini adalah 18 siswa pra-sekolah yang berumur antara tiga sampai lima tahun. Para peserta ini dibagi ke dalam dua kelompok berdasarkan latar belakang bahasa dan geografisnya. Temuantemuan menunjukkan bahwa kata-kata kerja jamak dan progresif (sedang berlangsung) memiliki keakuratan paling tinggi, sementara kata depan dan kata-kata kerja tidak beraturan 
lampau memiliki keakuratan yang paling rendah. Mengenai hubungan antara urutan pemerolehan, hasilnya mengungkapkan bahwa kajian ini menunjukkan urutan yang berbeda dibanding dengan hasil kajian Dulay dan Burt (1973) serta Brown (1973) melalui koefisien keselaran (coefficient of concordance) Kendall dan Korelasi Urutan Ranking (Rank Order Correlation) Spearman.

Katakunci: Keakuratan urutan, pemerolehan bahasa kedua, urutan pemerolehan, morfem tata bahasa

\section{INTRODUCTION}

Language acquisition has captured the interest of many researchers, whether it is first language (L1) or second language (L2) acquisition. Acquiring a language makes it possible for all humans to communicate through words. There are stages that a person has to undergo in order to acquire a language since no one is born talking and no one can instantly learn or acquire a language. According to Klima and Bellugi (1966), Slobin (1971), and Brown (1973) children go through the same language stages and show the same language learning behavior whatever language they are learning. The pattern of behavior suggests that children have to recognize the sounds around them first before they are able to distinguish the words spoken by people around them. This will be followed by identification of the meaning of the words, then construction of these words into sentences.

As can be noted, acquisition of grammatical morphemes is one of the phases in the acquisition of language (Aitchison, 1989). Morphemes are the smallest, indivisible units which are either meaningful by

Present progressive
Prepositions in
Prepositions on
Plural
Irregular past tense
Possessive
Uncontractible copula
Articles
Regular past tense
Third person present tense, regular

themselves or mark a grammatical function. They can be categorized as free morphemes whose roots are independent and bound morphemes whose roots depend on some other word-building element (Katamba \& Stonham, 2006). The free morphemes and the bound morphemes can be either lexical morphemes or grammatical morphemes. Lexical morphemes have consistent meanings and these can be classified as nouns, adjectives and verbs or affixes, while grammatical morphemes or functional morphemes are a set of functional words or inflections like "s" in cats, "ed" in talked, "ing" in dancing among others (Kies, 2008; Yule, 2006).

The pioneer in the study of the acquisition of grammatical morpheme was Brown (1973) who focused on first language acquisition. The subjects of Brown's longitudinal study were three children who aged 18 to 27 months old from the time the study began. Brown (1973) recorded the utterances of the children to see their grammatical development based on the focus of the study-acquisition of the 14 grammatical morphemes which are listed below:

I am singing
in the car
on the table
balls
broke, fell
Sister's pencil
This is hot
a, the
She laughed
He plays


Third person present tense, irregular

Uncontractible auxiliary

Contractible copula

Contractible auxiliary

In his study, Brown (1973) claimed that children's acquisition of morphemes is almost identical and that there is an order in their acquisition. He further stated that age and mean-length-of-utterance (MLU) combined are better predictors compared to age alone. After Brown's (1973) inciting study, a handful of researchers had conducted similar investigations both in L1 and L2 contexts. Various methods were also used in conducting researches on the acquisition of the said morphemes.

Using children as subjects, de Villier and de Villier (1973) conducted a cross-sectional study on the order of grammatical morpheme acquisition with 21 children who aged 16 to 18 months. They found that their findings closely resemble the findings obtained by Brown (1973). To find out if the order of first language grammatical acquisition is similar to L2, Dulay and Burt (1973) conducted a study using Spanish-speaking children who are immigrants in the USA. Through a speaking task and a technique called Bilingual Syntax Measure (BSM) which elicits structured conversation, the researchers discovered that eight of Brown's order of grammatical morphemes was correspondingly produced by the participants of the study (Dulay \& Burt, 1973). The similarities of the order of grammatical morpheme in both L1 and L2 acquisition strengthen the claim of Brown (1973) that there is indeed an order in acquiring grammatical morpheme. As Lightbown and Spada (1999) claimed, children's cognitive development and mastery of the language are part of their developmental sequence in which acquisition on grammatical morphemes is as well part of.

The order of grammatical morpheme acquisition may not be true in all cases. In
She does

She is dancing

He's a friend

She's singing

Hakuta's (1974) preliminary study on a fiveyear old Japanese girl using MLU, the result of the study did not correlate with the previous studies on the acquisition of grammatical morpheme. Thus, Hakuta (1974) further concluded that the result may be due to the number of participants, their L1, and their age. On the other hand, Bergvall (2006) showed in her study that the seventh grade Swedish students, 60 in numbers, possess the same acquisition order with Dulay and Burt's (1974) order. Moreover, in her study, she identified the mastered grammatical morphemes of the participants, which are the copula and plural $s$, and the non-mastered, which is the third person regular. These findings are also similar to the other studies on the acquisition order (Bergvall, 2006).

Many studies also used adult learners as subjects of their studies. For example, Bailey, Maden, and Krashen (1974) tested 73 adults which were grouped into two: the Spanishspeaking group consisted of 33 participants and the non-Spanish group consisted of 40 participants which represented 11 different languages. The results of their study showed that the two groups have similar sequence in acquiring grammatical morphemes. And when they compared their results to Dulay and Burt's (1973), they found out that the acquisition of grammatical morphemes between adults and children are similar.

Similarly, Larsen Freeman conducted a study on 24 adult second language students' (Arabic, Japanese, Persian, and Spanish) grammatical morphemes based on five (5) tasks: reading, writing, listening, imitating and speaking. The various tasks were used to find out if the order of the grammatical morpheme would exist in different tasks. The study later on found that the order is different 
from Dulay and Burt's (1974). This may be due to the participants' consciousness on grammar since the methodology allowed the participants to "monitor" their grammatical awareness and therefore it was speculated that the "natural order" of acquisition (Krashen, 1988). Although the result did not show any relationship with Dulay and Burt's (1974) order, it supported Hakuta's (1974) study. The results further showed that the eight morphemes acquired by the Japanese girl in Hakuta (1974) and the Japanese adults in Larsen-Freeman (1975) are significantly correlated. Larsen-Freeman (1975) claimed that her participants' language background did not affect the morpheme order.

Another study that differs from the "natural order" of acquisition was the corpusbased study of Izumi and Isahara (2004) on the acquisition order of Japanese English learners based on an error analysis. The researchers tested two hypotheses on the acquisition of grammatical morpheme. The first hypothesis was based on 1970s studies which stated that grammatical morpheme was acquired in common order by learners with different backgrounds, while the second hypothesis was based on 1980s studies of Japanese learner's acquisition order which stated otherwise. The results of the study concluded that the background of the learners can cause differences in the acquisition order. Furthermore, the variations were not only caused by L1 differences but also by the dissimilarity of the medium of production, both written and spoken (Izumi \& Isahara, 2004).

However, in Widiatmoko's (2008) study on the acquisition of English grammatical morpheme of a Vietnamese learner, he concluded that there are similarities and differences in the acquisition of grammatical order as compared to the previous studies of Brown (1973) and Krashen (1984) and that repetitions of the participants' utterances are recurrent. This may be because the participants wanted to have more time before producing another utterance (Sawir as cited in Widiatmoko, 2008). The differences of the results of the acquisition order may have been caused by several factors, such as background and language environment. Moreover, the different methodologies used by the various researchers, like the discrete-point test and integrative test, can cause the differences in the findings as well (Krashen, 1988).

Akande (2003), dealt with the acquisition of grammatical morpheme of Nigerian learners. In this study, Akande (2003) asked 60 senior secondary school students to compose an essay and to take an English grammar test afterwards. The grammar test was given in order to support the lack of grammatical morpheme produced in essays. Based on the tests given, Akande (2003) found out that the participants of the study lacked mastery of the grammatical morphemes and that they have difficulties in the use of past participle, possessives, past tense, and plural inflection. The results of the study were also then assumed to be due to L1 interference.

Other studies focused on particular grammatical morphemes and one of these studies is Ertekin's study (2007) on past tense morpheme acquisition of Turkish college student with the age between 18 to 21 . In her investigation, she probed whether Turkish morphology affected the acquisition of English, the second language. The researcher gathered her data through writing tasks and she discovered that the participants applied the phonological rules of their first language in their second language. Hence, a transfer, which is the "influence resulting from the similarities and differences between the target language and other languages which have been previously (and perhaps imperfectly) acquired" (Odlin cited in Lucas, 2009), has affected the acquisition of the grammatical morpheme.

In the Philippines, Barrot (2010) investigated the monitored written 
compositions of adult Filipino learners. The study aimed to find out the accuracy level of selected grammatical morphemes and its implications to teaching. The participants of the study were 25 students who have finished their English subjects in order not to affect the result of the study. The researcher then came up with the following conclusions: (1) the accuracy level was reached, (2) the differences of the "order" was found to be minimal compared to the "established accuracy order", and (3) the results showed great implication to grammar, both teaching and learning. This study further shows that "monitor", the conscious use of grammar, and "unmonitor", the unconscious use of grammar, do not affect the order which is opposed to in the previous studies of Larsen-Freeman (1975) for "monitor" and Krashen (1977) and Dulay, Burt \& Krashen (1982) for "unmonitor". The probable reason for this is that the participants were more focused in conveying their thoughts or ideas that they hardly noticed the syntactic features of the target language.

There are numerous studies in the order of acquisition of grammatical morphemes; however, no paper to the knowledge of the authors has explored the accuracy order and acquisition of grammatical morphemes of Filipino children. Thus, the present study is interested in investigating the accuracy order of the English grammatical morphemes of Filipino preschool pupils. Specifically, this paper sought to answer the following questions: (1) What grammatical morphemes have highest and lowest accuracy level by Filipino preschool pupils?, and (2) Is there any relationship between the order of grammatical morpheme acquisition of Filipino preschool pupils compared to the order of grammatical morpheme wherein English is the first language and English is the second language?

\section{METHOD}

The present study employs descriptive approach which sought to identify the acquisition order of grammatical morpheme of Filipino preschool pupils based on the 14 grammatical morphemes outlined by Brown (1973). With this in mind, this study employed descriptive statistics, Spearman rank order correlation, and Kendall coefficient of concordance to determine the degree of similarity and difference between the findings of this study and that of Brown's (1973) and Dulay and Burt's (1973) studies.

The participants involved in this study were 18 preschool pupils whose age ranges from three to five years old. These participants were divided into two clusters based on their linguistic and geographical background. Cluster A included eight preschool pupils from Monkayo, Compostela Valley Province in Mindanao and could speak two or three languages-English, Filipino or Cebuano. Cluster B included 10 preschool pupils from Metro Manila and could speak basic Filipino and English. These pupils from cluster B were obtained from the study of Lucas and Bernardo (2008) titled "Exploring Noun Bias in Filipino-English Bilingual Children." All participants from both clusters belonged to middle-class families. None of these participants were native or near-native speakers of English.

The instrument used in the present study was an interview guide which contains questions that would elicit utterances containing the target grammatical morphemes. Along with the interview guide was a picture storybook to further reinforce the oral production of the participants. This instrument was used in gathering data for cluster A. As regards cluster $\mathrm{B}$, since the data was elicited from naturalistic setting, the instrument used to gather data was an audio recorder. These two forms of instruments and data elicitation were used to elicit enough language samples for analysis.

Data gathering for cluster A participants was conducted in classroom setting. To build rapport and decrease the potential adverse 
effect of affect on the elicitation of data, a story telling was performed. Story telling was also done to provide participants with the necessary background knowledge on the possible questions that would be asked to them. After the storytelling, the participants were interviewed one by one in a conversational tone using a semi-structured format. Specifically, a semi-structured format was employed during the interview. Semistructured interview uses predetermined questions and topics that allow elaborations and is the most favored method among researchers working within an interpretative research. Further, semi-structured interview provides flexibility to both the interviewer and the interviewee (Nunan, 1991). The interview was undertaken in a private area in their school premises in the hope that they would be more comfortable in answering the posted questions regarding the story.

Unlike the data gathering for cluster A, data gathering for cluster B occurred in the participants' house. Further, other family members of the participants were instructed to perform their usual routines as natural as possible during the recording of the audio. This is to capture the natural interactions between the participants and caregivers. Both the caregivers and the pupils were informed that their interaction would be recorded for 30 minutes. The tape recorder was placed near the caregivers and participants for better quality of the audio recording (Lucas \& Bernardo, 2008).

In the two sets of data, the language elicitation technique used by the researcher was natural communication since this type of technique draws out the unconscious use of grammar rules when a person conveys his/her opinion or ideas (Dulay, Burt, \& Krashen 1982). In addition, all interactions with the participants were recorded and the recordings were transcribed for the analysis of the grammatical morpheme produced by the preschool pupils.

\section{Data Analysis}

For the analysis of the data gathered, the concept of suppliance in obligatory context (SOC) which was used by Brown (1973) in his study on the order of grammatical morpheme was used in the present study. He explained SOC as:

...grammatical morphemes are obligatory in certain context, and so one can set an acquisition criterion not simply in terms of output but in terms of output-where required. Each obligatory context can be regarded as a kind of test item which the child passes by supplying the required morpheme or fails by supplying none or one that is not correct. This performance measure, the percentage of morpheme supplied in obligatory context, should not be dependent on the topic of conversation or the character of the interaction. (Brown, 1973, p. 255)

Each obligatory occasion was noted and considered as a "test-item" and it was scored following Dulay and Burt's scoring procedure. A score of 0 was given for no morpheme supplied, 1 for misformed morpheme supplied and 2 for correct morpheme supplied. There were two scores for each occasion, namely the "actual score" which depended on the participant's performance and the "expected score" which was two points for each occasion. The scores of each grammatical morpheme were computed using "group mean method". However, those participants who had less than three obligatory occasions for a morpheme were not included in getting the "group mean".

To determine the similarities and differences of the order of grammatical morphemes acquired by the participants of this study and the order of grammatical morphemes acquired by the previous studies, the researcher used Kendall coefficient of concordance $(W)$. The formula in calculating 
the Kendall coefficient of concordance and its steps are as follows:

$$
\begin{aligned}
& W=\frac{\mathrm{s}}{1 / 12 \mathrm{k}^{2}\left(\mathrm{~N}^{3}-\mathrm{N}\right)} \\
& \mathrm{N}=\text { number of morpheme ranked } \\
& \mathrm{k}=\text { number of studies compared }
\end{aligned}
$$

To get the $\mathrm{S}$, the following steps were followed: (1) Total sum of each grammatical morpheme divided by $\mathrm{N}$ equals to mean rank; (2) Sum of each grammatical morpheme subtract by mean rank; and (3) Square of each of the results and sum it all up. To be more specific in determining the degree of similarity between the present study and each of the previous studies by Dulay and Burt (1973) and Brown (1973), the formula of rho was used:

$$
\text { rho }=1-\frac{6 \sum d^{2}}{\left(N^{3}-N\right)}
$$

\section{FINDNGS AND DISCUSSIONS}

\section{Grammatical Morphemes with the Highest and Lowest Accuracy Level?}

The obligatory occasions were scored and computed using the group mean method in order to get the accuracy level of the usage of the grammatical morphemes of Filipino Table 1: Accuracy level of the grammatical morphemes preschool pupils. As what Brown (1973) pointed out, the curve of performance that reaches $90 \%$ will most likely remain at this level. Thus, in this study $90 \%$ accuracy level will then be applied.

Table 1 shows that 7 out of 10 grammatical morphemes have reached 90 percent which is the set parameter for "acquiring" a morpheme (Brown, 1973) but not all 18 preschool pupils have produced three or more obligatory occasions on each grammatical morpheme. One probable reason behind this is the lack of conversation time; another is that the participants have not yet fully acquired the grammatical morphemes.

Among the 10 grammatical morphemes, singular/plural auxiliary - both contractible and uncontractible - and progressive have the same rank of 1.5 and these two grammatical morphemes have an accuracy rate of 100 percent. This can be due to perceptual salience, which "refers to how easy it is to hear or perceive a given structure" (Goldshneider \& DeKeyser, 2001). One of the samples from the data is shown below:

Mom: Where is the rocket going? Juancho: The rocket is going to the moon.

\begin{tabular}{lccc}
\hline Grammatical Morphemes & $\begin{array}{c}\text { Number of } \\
\text { Children }\end{array}$ & $\begin{array}{c}\text { Group Means } \\
\text { Method }\end{array}$ & Rank \\
\hline Singular/plural auxiliary & 6 & $100 \%$ & 1.5 \\
Progressive & 6 & $100 \%$ & 1.5 \\
Contractible copula & 8 & $99.43 \%$ & 3 \\
Uncontractible copula & 9 & $99.07 \%$ & 4 \\
Plural & 9 & $96.30 \%$ & 5 \\
Past regular & 5 & $89.88 \%$ & 6 \\
Articles & 13 & $89.60 \%$ & 7 \\
$3^{\text {rd }}$ Person regular & 3 & $85 \%$ & 8 \\
Prepositions (in and on) & 5 & $80 \%$ & 9 \\
Past irregular & 5 & $77.67 \%$ & 10 \\
\hline
\end{tabular}


In addition, the high level of accuracy rate of the progressive morphemes can be because of its "syllable" feature of saliency. According to Larsen-Freeman (1976), the position of the grammatical morpheme-whether it is a syllable or not can affect the perceptual saliency of the morpheme. In this study, the Filipino preschool pupils tend to use auxiliary and progressive in reference to present action even though the action is not ongoing but refering to future. For example,

Mom: What are we going to ride?

Juancho: We are going to ride a rocket ship.

The result further shows that the participants have the notion of "number" which is one of the factors of the semantic of auxiliary (Brown, 1973) and based on the examples below, the participant is able to provide auxiliary that agrees with its subject. On the first example, the subject - they requires an auxiliary "are" and on the second example, the subject — she - requires an auxiliary "is". Below are samples of conversation taken from the study:

Interviewer: How about this one? What are the birds doing?

Harvey: They are flying to the sky.

Interviewer: She lives in Luzon?

Harvey: Oh no! She's visit_-visiting in my house and now now, she is there in my house my house.

Furthermore, these two grammatical morphemes are often used by the adults in conversing with these children that is why they often hear it and eventually use it in communication. As what Brown (1973, p. 410) mentioned in his study, "the child will not learn what he cannot hear".

The third and fourth grammatical morphemes are copulas, the contractible and the uncontractible and the participants are almost 100 percent accurate in producing these two grammatical morphemes. Input frequency may be one of the determinants on why the children garner such high accuracy level (Guo, 2009). This means that they are able to produce the appropriate copula in respect to subject and time. When it comes to the use of copulas, out of 18 participants, eight participants have produced contractible copula while nine participants have produced uncontractible copula. Although uncontractible copula has more users compared to contractible copula, the accuracy level of the later is higher. It appears that in this study, the participants have earlier acquired bound morphemes: progressive, contractible copula, and plural compared to free morphemes. However, according to Wakabayashi (2001), free morphemes are acquired earlier compared to bound morphemes in second language acquisition due to its saliency, and the order is reversed in the first language acquisition (Krashen, 1988). Thus, the result shows that it follows L1 acquisition of grammatical morpheme in terms of bound morphemes to be acquired first and free morphemes to be acquired last. Then it may due to the participants' exposure to the target language assuming that these participants have already been exposed to English since birth due to the nature of their language environment, where English is widely used. If these children indeed acquired two languages at the same time, then these children might be "simultaneous bilingual". As what Paradis (2008) claimed, “ dual language children's acquisition of the morphological system in English might not lag behind those of monolinguals as much as their productive abilities would indicate as a result of time exposure". Therefore, this might be a probable reason why Filipino preschool children acquire bound morphemes first.

Following the copula, contractible and uncontractible, is plural (e.g., flowers and 
colors) which has 96.30 percent accuracy level. In Brown's (1973) study on first language acquisition, plural form is one of earlier acquired morpheme; however, in Hakuta's (1974) study, the plural form has about 60 percent accuracy level and in Wode, Bedey, and Frank (1978), only one form is used, either singular or plural, for both plural and singular intentions. On the other hand, the datum shows that the students are able to produce plural forms with almost no difficulties and that they have already grasp the concept of numbers. Children use "numeral marking" in contrasting singular and plural forms (Clark \& Nikitina, 2009) and they likely get the notion of plural form in adult speeches where they heard redundant plural markings (Bloom \& Wynn, 1997; Nicolaci-daCosta \& Harris cited in Clark \& Nikitina, 2009) like six birds and two dogs. As what can be seen below, Gabriel has used the word number "two" before the plural form of the noun "leg". This shows that children associate numbers which are more than one with plural forms. An illustration of this is shown below.

Mother: Ok, oh gosh, this one is too close, which ones match?

Gabriel: This one, this one doesn't match

Mother: Why?

Gabriel: because it has two legs, here and here

Mother: right, what about the others, how many legs do they have on each side?

Gabriel: one two three, one two three four, this one matches, see, here, see together, ok next, oh I like this.

As what one can be observed in the table, grammatical morphemes that have high accuracy level are function morphemes. This shows contrast to the claim of Gerken and McIntosh (1993), which state that monolingual
English-speaking children cannot verbally produce function morphemes though they are sensitive to these morphemes because of their morphological or syntactic complexity. This implies that Filipino preschool children are influenced in analyzing function morphemes because they are exposed to this kind of morphemes in their first language. For example, a Filipino child would say "Sila ay lumilipad" (They are flying) having a function morpheme of "ay" (are). Below are the examples from the data:

$\begin{array}{ll}\text { Interviewer: } & \text { What are the birds } \\ & \text { doing? } \\ \text { Corinne: } & \text { They are flying. } \\ \text { Interviewer: } & \text { How about this picture? } \\ & \text { What are the cat and the } \\ & \text { dog doing? } \\ \text { Corinne: } & \text { They are fighting. }\end{array}$

The grammatical morphemes that did not reach the 90 percent accuracy ceiling are past regular, articles, $3^{\text {rd }}$ person regular, prepositions and past irregular. Three out of five of these grammatical morphemes are verbs which indicate "time". For the past regular and irregular, the children need to have a concept of the past and Brown (1973) also mentioned that "irregular morphemes cannot be learned by general rule but must be individually memorized". The sample conversations from the data are shown below.

Rachelle: I go (went) to enchanted kingdom.

Thomas: I did not see you when you buy (bought) your cell phone

Gabriel: Ok, I color (ed) this already.

Articles, $a$ and the, have been used by the participants quite often because out of 18 participants, 13 are able to provide it. They give distinction whether the participants are refering to something specific or non-specific. However, they seem to over generalize the 
functions of ' $a$ ' and 'the' or misused it which is also found in Chinese and Malay ESL adult learners (Wong \& Quek, 2007). Even if the participants over generalized or misused the articles, they appear to know that most of the time it is required to have an article after a noun. The probable reason is that they have not yet fully distinguished the difference between definite and non-definite references. Examples are represented below.

Tristan: It's going to a moon.

Rachelle: The balloon is like this and then put a string there.

Gabriel: You point the letter and I'll color it.

Prepositions, in and on, are the second grammatical morpheme acquired by the participants in Brown's study (1973). However, the result of this study showed that preposition has the least accuracy level and this may due to L1 interference since Filipino language does not have separate label to prepositions 'in' and 'on'; both are called 'sa or nasa'. To further understand the preposition usage in Filipino, examples are given below.

The book is on the table (Ang libro ay nasa lamesa.)

The book is in my bag. (Ang libro ay nasa loob ng bag.)

The result of the prepositions is not surprising due to the nature of the preposition of the participant's first language and it is also mentioned in some studies that language interference is found in the errors of their participants. Thus, they concluded that language interference may be one of the factors that can affect the order of the acquisition of grammatical morpheme
(Akande, 2003; Ertekin, 2007; Goldschneider \& DeKeyser; 2001; Izumi \& Isahara, 2004; Kwon, 2005).

Possessive ' $s$ is eliminated from the study due to insufficient data. The participants are able to produce possessives but they are using possessive pronouns and not the $\mathrm{N}+\mathrm{N}$ type of construction like 'Daddy's car'. Even though the participants did not give sufficient data for possessive 's but then the participants understood the semantics of possession, as can be seen in the given two examples:

Daddy: Look what is inside

Pierce: That's my cup.

Daddy: That's your cup.

Mommy: O here's your food. O you eat it na. Ok?

Alyssa: How about my lemonade?

Mommy: Here's your lemonade. Sorry.

The other two grammatical morphemes that are also eliminated from the study are long plural and $3^{\text {rd }}$ person irregular due to lack of data to support any claims that may be inferred from these two grammatical morphemes.

The Order of Grammatical Morpheme Acquisition of Filipino Preschool Pupils Wherein English is the First Language and English is the Second Language

Most of the recent studies of the acquisition of the English grammatical morphemes are compared to the pioneering studies conducted by Brown (1973) for the L1 acquisition, and by Dulay and Burt (1974) for the L2 acquisition. Since Filipino preschool children are assumed to be simultaneous bilingual, the present study would like to compare the results of this study to the acquisition of English grammatical morpheme on both the L1 acquisition and the L2 acquisition.

Figure 1: Comparison of L1 and L2 studies on the acquisition of English grammatical morpheme 


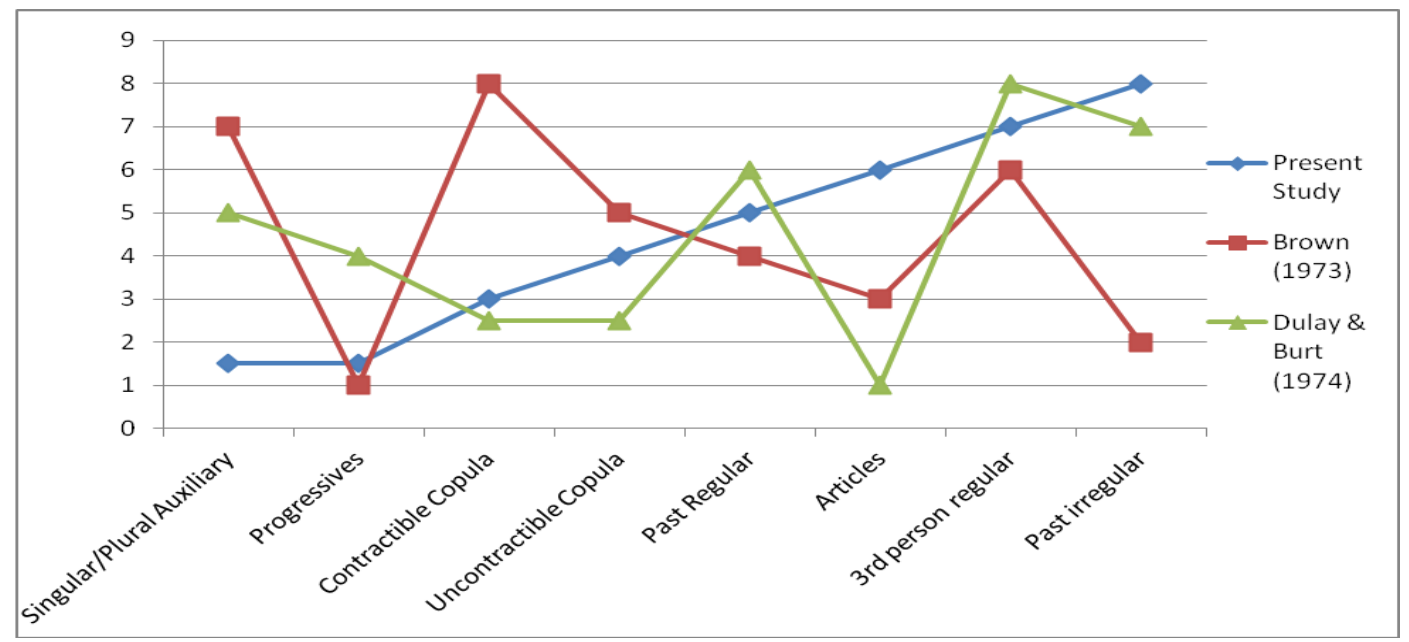

As shown in Figure 1, the present study, Brown's (1973), and Dulay and Burt's (1974) were ranked and compared through Kendall Coefficient of concordance. The findings revealed that there is not much significance in the relationship among these three studies (W= 0.36). This gives the impression that Filipino children, as highly exposed to two languages: English and Filipino, do not have the same order as those children who are acquiring their L1 and those children who are acquiring their L2. This may due to the fact that Filipino preschool pupils are assumed to be "simultaneous bilingual".

To fortify this result, the Spearman Rank Order Correlation was used to determine which of these previous studies have a relatively closer or farther relationship. The rho of the present study and Brown (1973) is 0.2321 and the rho of the present study and Dulay and Burt's study is 0.467 which shows that there is no correlation between the present study and the previous studies. However, it has to be noted that between the two studies, Brown (1973) and Dulay and Burt (1973), the former study has almost negative relationship. This shows that in the study of the acquisition order of grammatical morpheme, Filipino preschool pupils have higher degree of similarities with Dulay and Burt's (1973) order and this may be because both are acquiring English as a second language.
In view of the fact that the results of the present study are different from those of the aforementioned studies even though the researcher found some similarities implies that the acquisition of grammatical morphemes of Filipino preschool pupils could be hybrid in nature. According to Paradis (2008), if 2L1 (simultaneous bilinguals) acquisition follows after L1 or if there is a hybrid pattern between L1 and 2L1 then it supports the "maturational perspective", where age and input frequency act together as a driving of acquisition mechanism; however, if $2 \mathrm{~L} 1$ acquisition follows after L2 acquisition then this supports the "input-based perspective" which is due to the less exposure to L1 of 2L1 learners and L2 learners. Therefore, the age of the participants affects the cognition of these said participants, and the frequent occurrences of the grammatical morphemes in the environment of the participants play a major role in the acquisition of the grammatical morphemes.

\section{CONCLUSION}

The present study conducted aimed to investigate the acquisition of grammatical morphemes of Filipino preschool pupils with the age between 3 to 5 and the relationship between the findings of this study to the previous studies on the acquisition of grammatical morphemes of L1 and L2. Based on the gathered data and interpretation, it can 
be concluded that the participants of this study have acquired progressive -ing due to its perceptual saliency, and auxiliary, uncontractible and contractible due to its input frequency. In addition, they have demonstrated that they have concept of time and number because they were able to provide high percentage of accuracy when it comes to auxiliary, progressive -ing, copulas and plural $s$. However, they showed difficulties in acquiring past irregular due to the fact that it has to be memorized, especially articles for they have not distinguished between definite and indefinite references resulting to overgeneralization, prepositions because of L1 interference, and possessive 's. Although possessive 's was not produced by the participants, the participants' speech production revealed that they already understand the semantic of possession. With regard to the similarities of acquisition of L1 and L2 on grammatical morphemes, it appeared that the participants followed a different order than children acquiring English as their first language and as their second language, and this was proven by contrasting this study with Dulay \& Burt's (1973) and Brown's (1973) studies using Kendall coefficient of concordance and Spearman Rank Order correlation. The participants as simultaneous bilinguals could have contributed to this finding.

Pedagogically speaking, the teachers of preschool have to use frequently the grammatical morphemes that were acquired last through natural communication. In this way, children will have more exposure to the target language which eventually leads to higher accuracy level in acquiring grammatical morphemes in English. However, teachers must not impel preschool pupils to provide accurate grammatical morphemes when they are communicating because they only produce correct grammatical morphemes if they are already "cognitively ready" (Dulay \& Burt, 1973). Forcing students to use the correct grammatical morphemes will only lead to frustration to either teacher or students.

As a final thought, because of the exploratory nature of the present study and its limited number of participants, no conclusive claims are being advocated. Hence, the findings are open to challenge using the same methodology to test the reliability of the findings. It is also suggested that further studies be conducted using larger sample size belonging to various geographical and social demographics.

\section{REFERENCES:}

Aitchison, J. (1989). The articulate mammal: An introduction to psycholinguistics. London: Unwin Hyman.

Akande, A. T. (2003). Acquisition of the inflectional morphemes by Nigerian learners of English language. Nordic Journal of African Studies, 12(3), pp. 310-326.

Bailey, N., Madden, C., \& Krashen, S. (1974). Is there a "natural sequence" in adult second language learning? Language Learning, 24, pp. 235-243.

Barrot, J. (2010). Accuracy order of selected grammatical morphemes in the monitored written compositions of Filipino adult language learners. The Philippine ESL Journal, 4, pp. 45-65.

Bergvall, V. (2006). Young Swedish students's knowledge of English grammatical morphemes. Retrieved January 7, 2009, from www.divaportal.org/diva/getDocument?urn_nbn_se _kau_diva-817-1_fulltext.pdf -

Bloom, P., \& Wynn, K. (1997). Linguistic cues in the acquisition of number words. Journal of Child Language, 24(3), pp. 511-533

Brown, R. (1973). A first language: The early stages. Massachusetts: Harvard University Press.

Clark, E. V., \& Nikitina, T. (2009). One vs. more than one: Antecedents to plurality in 
early language acquisition. Linguistics, 47(1), pp. 103-139.

de Villiers, J., \& de Villiers, P. (1973). A cross-sectional study of the acquisition of grammatical morphemes in child speech. Journal of Psycholinguistics Research, 2, pp. 267-278.

Dulay, H., \& Burt, M. (1973). Should we teach children syntax? Language Learning, 24, pp. 37-53.

Dulay, H. \& Burt, M. (1974). Natural sequences in child second language acquisition. Language Learning, 27, 245258.

Dulay, H., Burt, M., \& Krashen, S. (1982). Language two. New York: Oxford University Press.

Ertekin, D. (2007). Acquisition of English grammatical morphemes. In K. BradfordWatts (Ed.), JALT2006 Conference Proceedings. Tokyo: JALT.

Gerken, L., \& McIntosh, B. (1993). Interplay of function morphemes and prosody in early language. Developmental Psychology, 29, pp. 448-457.

Goldschneider, J.M., \& DeKeyser, R.M. (2001). Explaining the "natural order of L2 morpheme acquisition" in English: A meta-analysis of multiple determinants. Language Learning, 51, pp. 1-50.

Guo, L.Y. (2009). Acquisition of auxiliary and copula BE in young English-speaking children. (Doctoral Dissertation). Retrieved from http://ir.uiowa.edu/etd/370

Hakuta, K. (1974). A preliminary report on the development of grammatical morphemes in a Japanese girl learning English as a second language. Working Papers in Bilingualism, 4(3), pp. 18-44.

Izumi, E., \& Isahara, H. (2004). Investigation into language learners' acquisition order based on an error analysis of a learner corpus. An interactive workshop on language e-learning, pp. 63-71. Retrieved January 7, 2009 from, http://dspace.wul.waseda.ac.jp/dspace/bits tream/2065/1396/1/07.pdf

Katamba, F., \& Stonhma, J. (2006). Morphology $\left(2^{\text {nd }}\right.$ ed.). NY: Palgrave Macmillan.

Kies, D. (2008). Word classes: an introduction. The Hyper textbook. Retrieved November 25, 2008 from, http://papyr.com/hypertextbooks/grammar /wd_intro.htm

Klima, E., \& U. Bellugi (1966) "Syntactic regularities in the speech of children." In J. Lyons \& R. Wales (Eds.), Psycholinguistic Papers (pp. 183-208). Edinburgh: Edinburgh University Press.

Krashen, S. (1977). Some issues relating to the monitor model. In H. Brown, C. Yorio, \& R. Crymes (Eds.). On TESOL ' 77. Washington: TESOL. pp. 144-158.

Krashen, S. (1984). Writing: Research, theory and applications. Beverly Hills: Laredo.

Krashen, S. (1988). Second language acquisition and second language learning. Prentice Hall International: UK.

Kwon, E. (2005). The "Natural Order" of morpheme acquisition: A historical survey and discussion of three putative determinants. Columbia University Working Papers in TESOL \& Applied Linguistics, 5(1), pp. 1-27.

Larsen-Freeman, D. (1975). The acquisition of grammatical morphemes by adult ESL students. TESOL Quarterly, 9(4), pp. 409412.

Larsen-Freeman, D. (1976). An explanation for the morpheme acquisition order of second language learners. Language Learning, 26, pp. 125-134.

Lightbown, P., \& Spada, N. (1999). How language is learned. Oxford: Oxford University Press.

Lucas, R., \& Bernardo, A. (2008). Exploring noun bias in Filipino-English bilingual children. The Journal of Genetic Psychology, 169(2), pp. 149-163. 
Lucas, R. (2009). Module in second language acquisition. Manila: De La Salle University.

Nunan, D. (1991). Research methods in language learning. Cambridge: Cambridge University Press.

Paradis, J. (2008). Are simultaneous and early sequential bilingual acquisition fundamentally different? Paper to be presented at Models of Interaction in Bilinguals, University of Wales, Bangor, October 24-26.

Slobin, D. (1971). Developmental psycholinguistics. In W. D. Dingwall (Ed.), A Survey of linguistic science. College Park: University of Maryland.

Wakabayashi, S. (2001). Why free morphemes are acquired earlier than bound morphemes: A minimalist account. PAC3 at JALT2001: Conference Proceedings.
Widiatmoko, P. (2008). Grammatical morpheme acquisition: an analysis of an EFL language learner's sample. Jurnal Sastra Inggris, 8(1), pp. 22-37. Retrieved December 2, 2008, from http://datafsastra.awardspace.com/jurnal0 208/artikel3.pdf

Wode, H., Bahns, J., Bedey, H., \& Frank, W. (1978). Developmental sequence: An alternative approach to morpheme order. Language Learning, 28(1), pp. 175-185.

Wong, B., \& Quek, S. T. (2007). Acquisition of the English definite article by Chinese and Malay ESL learners. Electronic Journal of Foreign Language Teaching. 4(2), pp. 210-234.

Yule, G. (2006). The study of language $\left(3^{\text {rd }}\right.$ ed.). New York: Cambridge University Press. 